\title{
PUBLICITY IN AFFAIRS OF INDUSTRIAL COMBINATIONS
}

\author{
Address by James R. Garfield, \\ Ex-Secretary of the Interior, Cleveland, Ohio.
}

\section{Ladies and Gentlemen:}

In considering the relation between the industrial combination and the national welfare we should first define national welfare and industrial combination.

National welfare is almost synonymous with the common good. It includes all phases of our national life. It is by no means confined, as some view it at times, to material welfare, prosperity that is measured in bank accounts, in great manufacturing institutions, and in wealth generally. It includes also our social, our moral and our political life. In both the national and in the state constitutions the promotion of the general welfare is expressed as being one of the prime objects of government. That purpose has very often been neglected or forgotten, and there are too many instances where we, as a people, have, instead of considering the general welfare, considered the special welfare, either of special sections of our country or of particular interests in our country. But to-night I wish to call your attention to the broader definition I have indicated.

What do we mean by industrial combinations? We there again must not be limited by the definition merely of a corporation or a business. Industrial combinations should not be considered simply as agencies of commerce, from the standpoint of the capitalist. We must include with the capitalist and with the capital invested, also the laborer and the labor put into the industrial combination. These two elements make up the combination. We must consider the rclation of these two elements of capital and labor, money invested, and muscle invested, and try to find out what their relation is, what it should be, to the general welfare.

It is, of course, a subject that is open to unlimited discussion, and there can be but a few of the phases of this discussion presented to-night. I shall try to present to you some of those that have been uppermost in my mind during the last ten years or more, while I 
have had the privilege of being a part of the movement that has had to do with the attempted solution of some of the difficulties. We will consider three phases of national welfare-industrial, social and political.

Industrial welfare is measured in great part by the financial returns to capital, labor and the public; but in connection with the financial or money side of industry there is the rafidly increasing importance of that phase of industry that has to do with the health and lives of the laboring men and women. Whether this question is approached from the side of mere money saving or from the higher and better side of humanity, it presents one of the most important subjects for consideration. Industrial prosperity depends upon the efficiency of labor and the highest efficiency can only be obtained when the conditions of labor are such as to develop individual efficiency. This element of industrial welfare includes hours of labor, conditions in workshop and factory, the living wage and similar problems.

Social welfare has to do with the lives of industrial workers outside the shop, mine or factory. It involves the consideration of family life, the education and training of children, the means for recreation and enjoyment and the actual living conditions in the great industrial centers. Social welfare therefore goes to the root of our national life, as it affects the character and morality of the generations to come. The tremendous importance of the problems involved in social welfare cannot be over-estimated. The future of our country depends upon the vitality and morality of its individual citizens.

Political welfare is the welfare of the community as a whole, whether it be the city, the state or the nation. The strength, efficiency and decency of these political divisions will depend upon the quality of the citizens who compose and control them. If citizens are indifferent to their political obligations it is inevitable that the political welfare of the community will be left to the hands of the professional boss, whose chief aim is certainly not the public welfare. No matter how good the system of government may be, it will become inefficient or corrupt unless the majority of the citizens are willing to devote time and intelligent effort to the consideration of political questions and the selection of proper public officers.

As we have thus roughly defined the national welfare, we must also define the industrial combination. These great industrial agents 
have not sprung up over-night, but are the growth of the last quarter of a century of our industrial life. It is a mistake to assail all great combinations because of the flagrant abuses that exist in some combinations. We must remember that the growth of the corporation, the consolidation, or the trust, has been for the most part under and in accordance with the laws of different states, laws that have been and are lax or vicious, but nevertheless laws adopted by the people or permitted to remain upon the statute books because of the indifference of the people themselves. It is in comparatively recent years that we have awakened to a full realization of the danger of unregulated and uncontrolled corporate action. We as a people have ourselves to blame for present conditions. We have been too anxious to make money and have measured success too often by money alone, with too little regard for the rights of the individual and the obligations that society as a whole has towards individuals.

The industrial combinations, practically always in the form of corporations, have developed with great rapidity and extended their fields of activity until in almost all industries there are corporations that deal with their products from the raw material to the door of the consumer. They engage in commerce and trade throughout the world, and employ thousands upon thousands of men and women. Their financial strength and the extent of their activities make them factors of vital importance in the industrial, social and political welfare of the nation. It is the relation of such combinations to the national welfare that we are considering.

The first step toward a proper understanding of conditions is of course a knowledge of the affairs of such combination. This knowledge can be obtained only by thorough, painstaking, fair investigation made by the public authority. Efforts in this direction have been made by both the states and by the national government.

The wiser and better leaders of business have co-operated with these public investigations realizing that there can be no injury to legitimate business by the full disclosure of business methods. The business leaders who have taken the opposite course first by denying the right of the public to investigate, and secondly by throwing every obstacle in the way of investigation, have done harm not only to their own corporations but have brought suspicion upon big business in general. However, the right of the public to investigate corporations has been firmly established, and all that is now necessary is for both the 
nation and the states to exercise thisright wisely, fairly and thoroughly, to the end that the public may have accurate information upon which to base the policy for the determination of the future relation between big business and the public.

The wiser leaders of big business have already done much toward the establishment of the right relations to the public. In many instances they have made investigations into the social and industrial welfare of their laborers, and have adopted methods for radical change in the improvement of both working and living conditions.

The national government and many of the states have enacted laws under which there has been a vast improvement in the living and working conditions of industrial workers, and the newer relation ketween the corporation and the public has been definitely established. The making of these changes has of course not been accomplished without friction and in too many cases has caused hostility, but I am one of those who have the utmost confidence in the ability of the American people to justly work out these problems. We can avoid injustice and excess if we are willing to-day to recognize the conditions that have already been developed, and begin now, not ten years from now, to try to improve those conditions. There is, of course, danger in going too fast, but there is still greater danger, if we follow the advice of those who are afraid to move at all, because they cannot see clear through to the end of the new order of things. The relation of the corporation to industrial and social welfare is of the greatest importance, and I have but suggested some of the questions that arise in that connection. I wish this evening especially to call your attention to the relation of great combinations to the public in the political sense.

The political relation of these bodies to the national welfare is totally different from the relation of the individuals of which they are made up. Politically every one of these organizations or associations is entitled to fair treatment, to a full hearing on any question that affects its work, its opportunities, its profits, its methods, but not one of them is entitled to a voice in politics, to representation in public office, or to influence over public officers. It is because many corporations have either interfered or attempted to interfere in politics, that the outcry is made against them. When a railroad or a great industrial corporation has exercised influence over the legislative bodies of the commonwealth, or has controlled 
the selection of men in public office, that corporation has gone entirely outside of its proper and legitimate sphere of action, and has become an enemy to the public welfare and the common good. I grant you that there have been instances in which, on the other side, men in public office have been unjust and unfair to corporations, have sought to hold up the corporation and have used their political power for the benefit of themselves rather than for the good of their constituents; but because that is true it does not excuse the corporation for improper action. We must see to it that all this kind of relation between corporations and the public shall cease. It will not be done in a day, it will not be done in a year, but we should face sternly the road that lies away from that kind of relationship between industry and our political life. We should strive in every one of our commonwealths and in the nation to keep out of office men who stand as representatives of any one of these particular, special interests. And let me again emphasize this: when I use the words "special interests," I apply equally to the labor union, to the farmers' alliance, and to the corporations. Not one of them should be permitted to have a representative in any public office. That is one of the first steps for changing the evil conditions that exist in many places.

Now another step that should be taken is this. I am not at all content to leave the question of the proper regulation of the greater industrial corporations to the courts. The courts have their very proper and necessary functions, but these functions are not to make a law or to devise a system, or a plan by which the great business of this country shall be conducted. If we are to provide a plan that plan must be made by the legislative and not by the judicial bodies. That plan must be placed in the hands of executive officers, not judicial officers, if it is to be efficiently carried out. Congress should provide a method similar to that which is provided for the national banks or for the railroads. It is quite immaterial whether it be a bureau or a commission, as the form is immaterial if the power be given. There must be an executive body which will primarily act as the Comptroller of the Currency, or as the Interstate Commerce Commission acts, so that the men engaged in industry will know beforehand exactly how they can act, what they can do, and further be assured that when they have complied with the law they will be free from litigation, so long as they continue to obey the law. In addition to that there should be a clear definition of those acts which 
result in criminal proceedings. It is not fair to industry to leave uncertain or indefinite, the actions that may be considered crimes. It was well said this afterncon that trade had gone faster than the law in development during these last twenty-five years. We must now put law in harmony with sound business. The business men of this country must know whether they are dealing fairly or unfairly. We must adapt our laws to the industrial changes. We must not attempt to continue laws that are contrary to the wise industrial development of the age. That is why I have been opposed to the anti-trust law as it stands to-day. It has in it some excellent features, features that should not be changed, but it is likewise an unworkable law as it now stands. The recent interpretation by the Supreme Court did not relieve the law of its indefiniteness, nor do those decisions lay down definite rules for the organization, management and conduct of the great industrial combinations. A single state cannot control the great interstate corporations. The nation is the only sovereignty that can control them. The nation is the only government big enough and strong enough to cope with the modern-day industrial combination.

The basis of the proposed legislation should be publicity. Publicity is the foundation of honest dealing and of the right relation between industry and the public welfare. If you and I are permitted to hide behind a corporation, great or small, and be free from public inspection or supervision, we then have every opportunity to do that which will be unfair toward our competitors, unfair toward the public. Publicity takes away both the opportunity and the temptation to do wrong. Publicity makes possible an intelligent public opinion, based upon the facts. The mere fact that the railroads to-day are doing their business in the open makes it almost impossible for them to engage in the character of abuses that existed a few years ago. The national bank is open to public inspection and its directors will hesitate a long time before doing that which would bring upon them the criticism of their community.

With publicity as the basis, constructive legislation for the supervision, regulation and control by the federal government of the greater industrial corporations is comparatively simple. The experience we have had with the railroads and the national banks shows that the executive not the judicial branch of government is the proper agency for this work. The investigations that have already been made give 
us facts upon which to start. There should be no further delay in enacting the legislation.

It was suggested in the discussion that the logical effects, the necessary result of such legislation would mean the fixing of prices. Now that may be true and yet it is not true that we should be afraid to take that step because of the logical conclusion. You will find that logical conclusions seldom happen in public affairs. Many elements will come in to change conditions from time to time; many new phases will develop which we in this day cannot appreciate; any or all of which may completely change the course that to-day seems clear. Therefore we should not hesitate to do that which we consider wise now, because we fear that in the future there may be some dilemma which looks insuperable at this time. 